\title{
Significant Inhibition of Porcine Epidemic Diarrhea Virus In Vitro by Remdesivir, Its Parent Nucleoside and $\beta$-D-N $\mathrm{N}^{4}$-hydroxycytidine
}

\author{
Yuanchao $\mathrm{Xie}^{1} \cdot$ Xiaozhen $\mathrm{Guo}^{2} \cdot{\text { Tianwen } \mathrm{Hu}^{1} \cdot \text { Daibao } \mathrm{Wei}^{1} \cdot \text { Xiuli } \mathrm{Ma}^{2} \cdot \text { Jiaqiang } \mathrm{Wu}^{2} \cdot \text { Bing Huang }}^{2}$ (D) \\ Jingshan Shen ${ }^{1,3}$ (1)
}

Received: 15 October 2020 / Accepted: 22 January 2021 / Published online: 22 March 2021

(c) Wuhan Institute of Virology, CAS 2021

\begin{abstract}
Porcine epidemic diarrhea (PED) caused by porcine epidemic diarrhea virus (PEDV) is widespread in the world. In recent years, the increased virulence of the virus due to viral variations, has caused great economic losses to the pig industry in many countries. It is always worthy to find effective therapeutic methods for PED. As an important class of antivirals, nucleoside drugs which target viral polymerases have been applied in treating human viral infections for half a century. Herein, we evaluated the anti-PEDV potential of three broad-spectrum antiviral nucleoside analogs, remdesivir (RDV), its parent nucleoside (RDV-N) and $\beta$-D- $\mathrm{N}^{4}$-hydroxycytidine (NHC). Among them, RDV-N was the most active agent in Vero E6 cells with $\mathrm{EC}_{50}$ of $0.31 \mu \mathrm{mol} /$ $\mathrm{L}$, and more potent than $\mathrm{RDV}\left(\mathrm{EC}_{50}=0.74 \mu \mathrm{mol} / \mathrm{L}\right)$ and $\mathrm{NHC}\left(\mathrm{EC}_{50}=1.17 \mu \mathrm{mol} / \mathrm{L}\right)$. The activity of RDV-N was further confirmed using an indirect immuno-fluorescence assay. Moreover, RDV-N exhibited a good safety profile in cells and in mice. The high sequence similarity of the polymerase functional domains of PEDV with other five porcine coronaviruses indicated a broader antiviral spectrum for the three compounds. Generally, RDV-N is a promising broad-spectrum antiviral nucleoside, and it would be worthy to make some structural modifications to increase its oral bioavailability.
\end{abstract}

Keywords Porcine epidemic diarrhea virus (PEDV) $\cdot$ Nucleoside analog $\cdot$ RNA dependent RNA polymerase (RdRp) Antiviral activity

\section{Introduction}

Porcine epidemic diarrhea virus (PEDV) is an enteropathogenic alpha coronavirus which can cause porcine epidemic diarrhea (PED), a highly contagious swine disease that is prevalent among pig herds. PEDV was first identified in the 1970s, and in the following decades, it did not cause a significant impact on the pig industry until the emergence of

Yuanchao Xie and Xiaozhen Guo contributed equally to this work.

Jingshan Shen

shenjingshan@simm.ac.cn

$\triangle$ Bing Huang

hbind@163.com

1 Shanghai Institute of Materia Medica, Chinese Academy of Sciences, Shanghai 201203, China

2 Institute of Poultry Science, Shandong Academy of Agricultural Sciences, Jinan 250023, China

3 University of Chinese Academy of Sciences, Beijing 100049, China new variant strains with high virulence in the 2010s. Since then, PEDV outbreaks have frequently occurred throughout the world, especially in China and some Asian countries (Lee 2015). Vaccination has been the primary measure for the prevention of PEDV. However, due to the emerging genetic variants, the current PEDV vaccines are not guaranteed to be effective. Generally, for the suckling piglets which are most vulnerable to PEDV, the mortality rate could reach $100 \%$ (Ma et al. 2015). Considering the great threat to the pig industry, it's meaningful to find more effective methods for the prophylaxis and treatment of PED in the long run.

Besides vaccination, some potential therapeutic methods for PED have also been reported, such as neutralizing antibodies (Gong et al. 2018; Zhang et al. 2019), anti-inflammatory factor (Li et al. 2019), peptides (Zhao et al. 2018), and small chemical molecules. Among them, small chemical molecules including natural products and synthetic compounds attract the most attention. Glycyrrhizin and glycyrrhizic acid, two active components of glycyrrhiza uralensis that is a common Chinese herb, have been characterized with various biological activities. Recently, the 
two compounds are found to effectively inhibit the PEDV infection in Vero cells by multisite inhibition mechanisms (Huan et al. 2017; Tong et al. 2020). The oleanane triterpenes and prenylated phenolic compounds from natural plants are also identified as PEDV proliferation inhibitors, some of them could inhibit viral replication at sub-micro molar level (Cho et al. 2019; Yang et al. 2015). In 2020, Peng et al. reported that GC376, a well-known broad-spectrum inhibitor of $3 \mathrm{CL}^{\text {pro }}$ was highly effective against the PEDV $3 \mathrm{CL}^{\text {pro }}$ with $\mathrm{IC}_{50}$ value of $1.11 \mu \mathrm{mol} / \mathrm{L}$. The structural basis for inhibiting this enzyme was elucidated, providing important information for the structural optimization of GC376 (Ye et al. 2020).

At the end of 2019, a new human coronavirus, named SARS-CoV-2 emerged and rapidly spread around the world, infecting nearly 98 million people and causing more than 2.0 million deaths by January 21st, 2021 (Valencia 2020). During this pandemic, an antiviral drug, remdesivir (RDV), which was previously indicated for Ebola virus infection, was authorized for emergency use against the viral infection on May 1st, 2020, and officially approved soon based on the positive results of three clinical trials (Beigel et al. 2020; Goldman et al. 2020; Spinner et al. 2020). RDV is a $1^{\prime}-$ cyano-substituted adenosine nucleotide analogue prodrug which acts as a non-obligated chain terminator by targeting the highly conserved active site of viral polymerase and shows broad-spectrum antiviral activity against an array of RNA viruses, such as HCV, MERS virus, SARS-CoV virus, and Ebola virus (Agostini et al. 2018; Cho et al. 2012; Siegel et al. 2017). Moreover, this antiviral candidate is found to be able to inhibit zoonotic deltacoronaviruses with highly divergent RNA dependent RNA polymerases (RdRps), highlighting the value of this drug in the fighting against future emerging viruses (Brown et al. 2019). $\beta-\mathrm{D}-\mathrm{N}^{4}$-hydroxycytidine, NHC, reported as early as 1959 (Fox et al. 1959) is also found to be a broad-spectrum antiviral nucleoside which has recently received a great deal of attention due to its potential for the treatment of SARS-CoV-2 infection (Sheahan et al. 2020b; Yoon et al. 2018).

As is well known, nucleoside analogs are an important source for discovering antiviral agents, and till now more than twenty-five drugs of this class have been approved for treating human viral diseases (Seley-Radtke and Yates 2018; Yates and Seley-Radtke 2019). However, with respect to animal viral diseases, little is known on the therapeutic potential of such kind of antivirals. PED is a serious disease that is lethal to piglet, and it is very meaningful to find effective anti-PEDV drugs. Herein, we evaluated the antiPEDV activities of RDV, RDV nucleoside (RDV-N), and NHC, whose molecular structures were shown in Fig. 1. We found that RDV-N was the most active antiviral relative to its prodrug, RDV, and NHC. Moreover, RDV-N exhibited a high safety profile in mice which makes it to be a promising antiviral for the treatment of PEDV infection.

\section{Materials and Methods}

\section{Viruses, Cells and Mice}

African green monkey kidney cells (Vero E6 cells) were cultured in Dulbecco's modified Eagle's medium (DMEM), supplemented with $10 \%$ fetal bovine serum (Invitrogen, Carlsbad, CA, USA) at $37{ }^{\circ} \mathrm{C}$ with $5 \% \mathrm{CO}_{2}$. The PEDV variant strain SDSX16 (Accession no. MH117940.1) was isolated from a sucking piglet with acute diarrhea. Male ICR mice (18-22 g) were purchased from Shanghai Super-B\&K Laboratory Animal Co. Ltd. (Shanghai, China).

\section{RDV/RDV-N/NHC}

RDV, RDV-N, and NHC were synthesized according to the reported methods (Purohit et al. 2012; Siegel et al. 2017) and the structures were determined by nuclear magnetic resonance. The samples used for in vitro and in vivo study were in a purity of at least $98.5 \%$ by high-performance liquid chromatography analysis.

\section{Cytotoxicity Assays}

To assess the cytotoxicity of RDV/RDV-N/NHC in Vero E6 cells, cells were seeded in 96-well plates and allowed to grow for $24 \mathrm{~h}$ to reach $80 \%$ confluence, and then treated with the test compounds (RDV/RDV-N/NHC) diluted with serumfree DMEM containing $10 \mu \mathrm{g} / \mathrm{mL}$ trypsin (Sigma, St. Louis, MO, USA) at a final concentration of $500 \mu \mathrm{mol} / \mathrm{L}$, $250 \mu \mathrm{mol} / \mathrm{L}, 125 \mu \mathrm{mol} / \mathrm{L}, 62.5 \mu \mathrm{mol} / \mathrm{L}$ and $31.25 \mu \mathrm{mol} / \mathrm{L}$. DMSO was used as the blank control. The cells were then cultured at $37{ }^{\circ} \mathrm{C}$ for $72 \mathrm{~h}$, and the cytotoxicity was determined by CCK- 8 assay.

\section{Anti-PEDV Activity Assay}

Vero E6 cells were seeded in 96-well plates for $24 \mathrm{~h}$ and washed thrice with serum-free medium. PEDV (0.01 MOI) was first incubated with serial dilutions of the test compounds (RDV/RDV-N/NHC) at $37{ }^{\circ} \mathrm{C}$ for $1 \mathrm{~h}$ before infecting the Vero E6 cells. The final concentrations of RDV and RDV-N ranged from $125 \mu \mathrm{mol} / \mathrm{L}$ to $0.1 \mu \mathrm{mol} / \mathrm{L}$, and the concentration of NHC ranged from $62.5 \mu \mathrm{mol} / \mathrm{L}$ to $0.5 \mu \mathrm{mol} / \mathrm{L}$. DMSO was set as the blank control. The mixture was incubated at $37{ }^{\circ} \mathrm{C}$ until the cells of the virus control group showed complete cytopathic effect (CPE). The characteristic morphological changes of PEDV-infected cells in the antiviral groups were observed and photographed. 
Fig. 1 The chemical structures of RDV, RDV-N, and NHC.

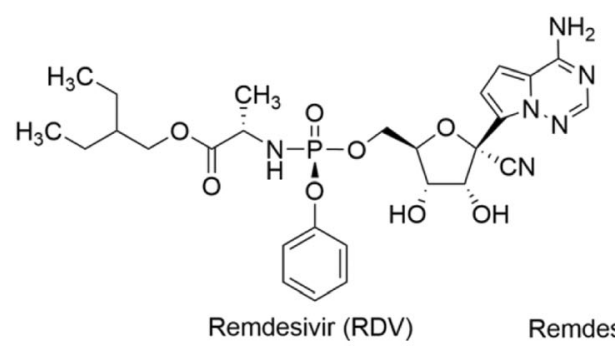

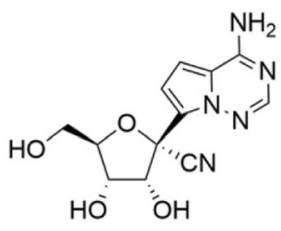

Remdesivir nucleoside (RDV-N)

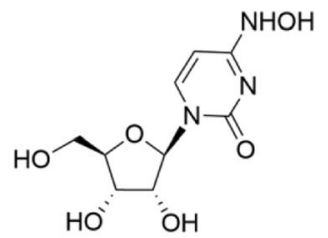

$\beta$-D-N4-hydroxycytidine (NHC)
In another experiment, after adding the PEDVcompounds dilution to the cells, the mixture was incubated at $37^{\circ} \mathrm{C}$ for $48 \mathrm{~h}$ and $72 \mathrm{~h}$, respectively. Cells and supernatants were harvested to determine viral loads and titers using quantitative real-time RT-PCR (qRT-PCR) and 50\% tissue culture infectious dose $\left(\mathrm{TCID}_{50}\right)$ assay, respectively. The effective concentration that reached $50 \%$ decrease in viral replication was defined as the $\mathrm{EC}_{50}$ value.

\section{Indirect Immuno-Fluorescence Assay (IFA)}

Vero E6 cells were cultured in 24-well plates for $24 \mathrm{~h}$ and washed thrice with serum-free medium. PEDV (0.01 MOI) was first incubated for $1 \mathrm{~h}$ at $37{ }^{\circ} \mathrm{C}$ in the presence of $0.2 \mu \mathrm{mol} / \mathrm{L}$ RDV-N before infecting Vero cells. DMSO was used as the blank control. Viral propagation was confirmed by daily observation of the CPE. After $48 \mathrm{~h}$ at $37{ }^{\circ} \mathrm{C}$, cells were fixed with $4 \%$ paraformaldehyde for $15 \mathrm{~min}$ at room temperature (RT) and then blocked with $1 \%$ bovine serum albumin (BSA) in PBS for $30 \mathrm{~min}$ at RT. The monoclonal antibody specific against PEDV spike protein was added to the cells as primary antibodies and incubated for $1 \mathrm{~h}$ at $37^{\circ} \mathrm{C}$. After washing three times with PBS, cells were incubated with FITC-conjugated anti-mouse IgG (Southern Biotech, Birmingham, AL, USA) in the dark for $30 \mathrm{~min}$ at $37^{\circ} \mathrm{C}$. After washing five times with PBS, the images were captured using a fluorescence Leica DM IL LED microscope (Leica, Wetzlar, Germany).

\section{PEDV Genomic and Subgenomic qRT-PCR Assay}

96-Well plates of Vero E6 cells were prepared, infected, and treated similarly to those described above. After $48 \mathrm{~h}$ or $72 \mathrm{~h}$, cells were harvested and total RNA was extracted from Vero E6 cells using the TRIzol reagent (Invitrogen) according to the manufacturer's protocol, and was then reverse-transcribed into cDNA using oligo (dT) as the primer (Invitrogen). Relative quantitative real-time PCR was performed in a Roche Light Cycler 96 real-time PCR system. The real-time PCR results were analyzed and expressed as relative expression of CT (threshold cycle) valuing the $2^{-\Delta \Delta \mathrm{Ct}}$ method. The primers used for PEDV and GAPDH were listed below: PEDV-F: 5'-CGTACAGGTAAGTCAATTAC-3';
PEDV-R: 5'-GATGAAGCATTGACTGAA-3'; GAPDH-F: 5'-ACATCATCCCTGCCTCTACTG-3'; GAPDH-R: 5'-C CTGCTTCACCACCTTCTTG- $3^{\prime}$.

\section{$\mathrm{TCID}_{50}$ Assay}

Virus stock solutions described above (48 h post infection) were serially diluted before they were inoculated on the confluent Vero cell monolayers grown in the 96-well plates, followed by washing three times with PBS. Eight wells were inoculated with $100 \mu \mathrm{L}$ at each dilution, and plates were incubated at $37{ }^{\circ} \mathrm{C}$ with $5 \% \mathrm{CO}_{2}$ for 2 days. The wells with syncytium formation, the specific CPE caused by PEDV, were classified as PEDV-positive. PEDV titration was calculated by TCID $_{50}$ following the Reed-Muench method.

\section{Pharmacokinetics Study of RDV-N in ICR Mice}

Six male ICR mice were randomly divided into two groups. Group 1 was received a single intravenous (IV) administration of $25 \mathrm{mg} / \mathrm{kg}$ RDV-N dissolved in 5\% DMSO, 5\% ethanol, 40\% PEG300, and 50\% saline (pH 5-6 with $0.1 \mathrm{~mol} / \mathrm{L} \mathrm{HCl}$ ), and Group 2 was received a single oral (PO) administration of $50 \mathrm{mg} / \mathrm{kg}$ RDV-N dissolved in DMSO/0.5\% HPMC $(5 / 95, v / v)$. The blood sample was collected at $5 \mathrm{~min}, 15 \mathrm{~min}, 30 \mathrm{~min}, 1.0 \mathrm{~h}, 2.0 \mathrm{~h}, 4.0 \mathrm{~h}$, $8.0 \mathrm{~h}$, and $24 \mathrm{~h}$ post-dosing, respectively, and the separated plasma was analyzed by LC/MS/MS. Mean plasma concentrations of RDV-N were used to calculate the pharmacokinetic parameters by noncompartmental analysis.

\section{Acute Toxicity Study of RDV-N in ICR Mice}

Fifteen male ICR mice were randomized into three treatment groups, with five animals per group. The three groups of animals were dosed once with RDV-N at 200, 500, and $1000 \mathrm{mg} / \mathrm{kg}$ orally, respectively (formulation: 5\% DMSO $+5 \%$ Solutol HS15 + 90\% saline). After administration, the mice were observed for 7 days (general signs, behavioral observation, body weight, and food consumption). 


\section{Metabolism of RDV and GS-441524 in Vero E6 Cells}

Vero E6 cells were seeded in a 6-well plate at $3.6 \times 10^{5}$ cells/well. After incubation for $24 \mathrm{~h}$, half of the culture media ( $89 \%$ DMEM $+10 \%$ FBS $+1 \%$ sodium pyruvate) was removed from each well followed by the addition of $20 \mu \mathrm{mol} / \mathrm{L}$ RDV or RDV-N dissolved in the culture media and DMSO $(99 / 1, v / v)$. The final concentration of RDV or RDV-N was $10 \mu \mathrm{mol} / \mathrm{L}(n=3)$. Twenty-four hours later, the cells were harvested and lysed in $100 \mu \mathrm{L}$ methanol/ water $(7 / 3, v / v)$. The nucleoside triphosphate metabolite was analyzed by LC/MS/MS.

\section{Results}

\section{Cytotoxic Activities of RDV, RDV-N, and NHC}

The cytotoxic effects of RDV, RDV-N, and NHC towards Vero E6 cell were determined before the antiviral assay. As shown in Fig. 2, both of RDV and RDV-N exhibited low cytotoxicity against Vero cell line with the maximal nontoxic concentrations (MNTC) of $125 \mu \mathrm{mol} / \mathrm{L}$, and $\mathrm{NHC}$ showed a higher cytotoxicity with MNTC of $31.25 \mu \mathrm{mol} / \mathrm{L}$.

\section{Anti-PEDV Activities of RDV, RDV-N, and NHC}

PEDV infection of Vero cells can cause cytopathic effect (CPE). To determine whether the three nucleoside analogs possessed ant-PEDV activities, we investigated their effect on the morphological changes of PEDV-infected Vero E6 cells. As shown in Fig. 3, Vero E6 cells uninfected by PEDV were mainly in polygonal or irregular shape with clear outline (Fig. 3A), and not affected by $0.1 \%$ DMSO (Fig. 3B), while PEDV significantly caused cell fusion and the normal morphology of cells could not be observed (Fig. 3C). For the experiment groups, the PEDV-induced CPE was obviously blocked by the treatment with RDV, RDV-N, and NHC at the concentration of $0.5 \mu \mathrm{mol} / \mathrm{L}, 0.2 \mu \mathrm{mol} / \mathrm{L}$, and $1.0 \mu \mathrm{mol} / \mathrm{L}$, respectively (Fig. 3D-3F, Figures of high concentrations were not shown).

To measure the antiviral activities of the three compounds against PEDV, we used quantitative real-time RTPCR (qRT-PCR) and TCID $_{50}$ assay to determine the viral loads and titers in the infected cells, respectively. It was obvious to find that the viral genomic copies, as well as the viral titer, were decreased by all the three compounds in a dose-dependent manner at $48 \mathrm{~h}$ post infection (Fig. 4). Among them, RDV-N exhibited the strongest antiviral activity, and the virus replication was completely inhibited at the concentration of $2.0 \mu \mathrm{mol} / \mathrm{L}$. Further, the $\mathrm{EC}_{50}$ values of them were determined at $72 \mathrm{~h}$ post infection using qRT-PCR. RDV-N had an $\mathrm{EC}_{50}$ value of $0.31 \mu \mathrm{mol} / \mathrm{L}$ which was twice active as its phospharamidate prodrug, $\operatorname{RDV}\left(\mathrm{EC}_{50}=0.74 \mu \mathrm{mol} / \mathrm{L}\right)$, and 3-folds more potent than $\mathrm{NHC}\left(\mathrm{EC}_{50}=1.17 \mu \mathrm{mol} / \mathrm{L}\right)$, shown in Fig. 5 .

Moreover, we used an indirect immuno-fluorescence assay (IFA) to further confirm the anti-PEDV capacity of RDV-N. The viral protein expression level could be regarded as an indicator of viral quantity. From Fig. 6B and $6 \mathrm{C}$, it can be found that the fluorescence intensity was significantly decreased in the presence of $0.2 \mu \mathrm{mol} / \mathrm{L}$ RDV-N, which strongly supported the potent antiviral activity of RDV-N.

\section{Pharmacokinetics, In Vitro Metabolism and Acute Toxicity Studies of RDV-N}

The pharmacokinetics of RDV-N was studied in ICR mice. As a nucleoside, RDV-N displayed poor water solubility and low lipophilicity. Predictably, this nucleoside demonstrated a low bioavailability $(15.7 \%)$ in mice (Table 1 ). After oral administration, RDV-N rapidly reached the maximal plasma concentration within $1 \mathrm{~h}$, and was eliminated quickly, similar to the data of intravenous administration. As an antiviral nucleoside, the active form of RDV-N was the nucleoside triphosphate (NTP) metabolite
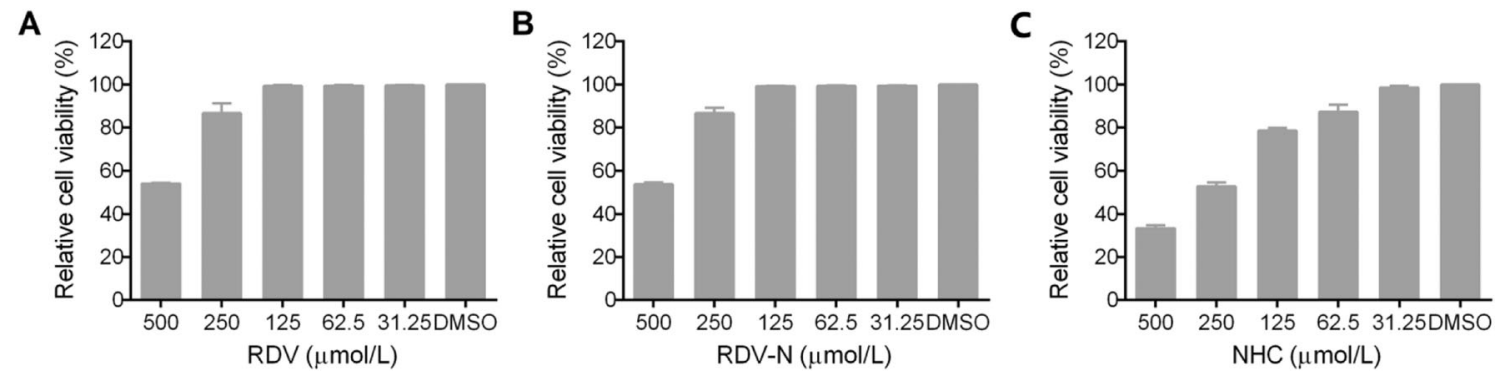

Fig. 2 Cytotoxicity of RDV, RDV-N, and NHC in Vero E6 cells. Vero E6 cells were treated with indicated concentration of test compounds for $72 \mathrm{~h}$, and cell viability was measured by CCK-8 assay. A The MNTC of RDV was $125 \mu \mathrm{mol} / \mathrm{L}$. B The MNTC of RDV-N was $125 \mu \mathrm{mol} / \mathrm{L}$. C The MNTC of NHC was $31.25 \mu \mathrm{mol} / \mathrm{L}$. 
A

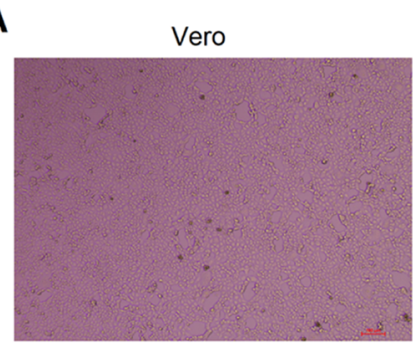

D

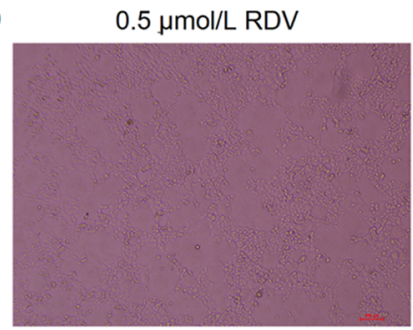

B

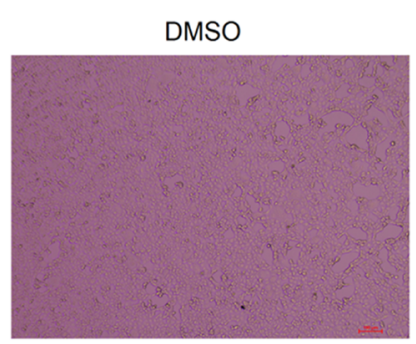

E

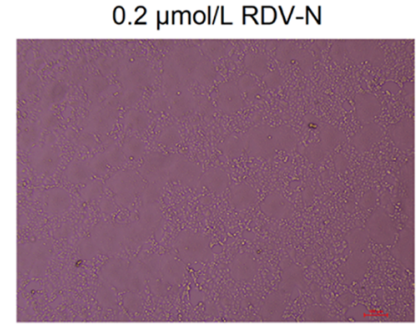

C

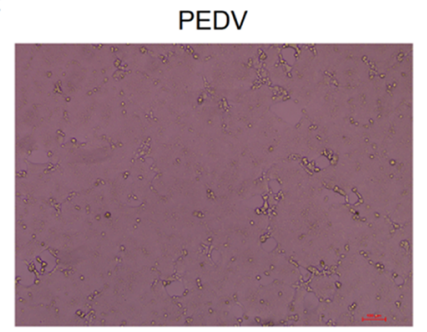

$\mathbf{F}$

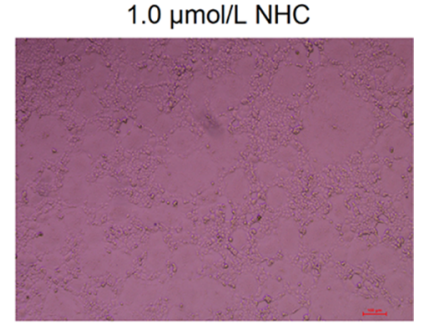

Fig. 3 The effects of RDV, RDV-N, and NHC on PEDV-induced CPE. Vero E6 cells were seeded in 96-well plates for $24 \mathrm{~h}$ and washed thrice with serum-free medium. PEDV (0.01 MOI) was incubated with serial dilutions of test compounds at $37{ }^{\circ} \mathrm{C}$ for $1 \mathrm{~h}$ before infecting the Vero E6 cells. The mixture was incubated at $37^{\circ} \mathrm{C}$ until the virus control group showed complete CPE. The characteristic morphological changes of PEDV-infected cells were photographed. A Non-infected cells. B Non-infected cells with $0.1 \%$ DMSO. C Cells infected with PEDV. D PEDV-infected cells with $0.5 \mu \mathrm{mol} / \mathrm{L} \mathrm{RDV}$. E PEDV-infected cells with $0.2 \mu \mathrm{mol} / \mathrm{L}$ RDV-N. F PEDV-infected cells with $1.0 \mu \mathrm{mol} / \mathrm{L} \mathrm{NHC} \mathrm{(scale} \mathrm{bar:} 100 \mu \mathrm{m}$ ).
A

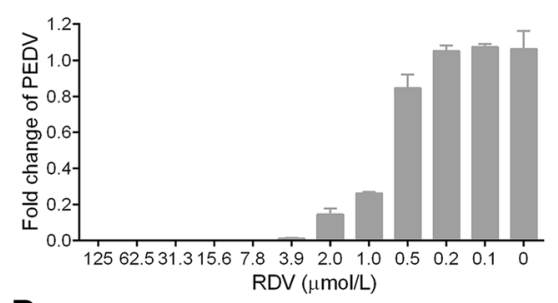

D

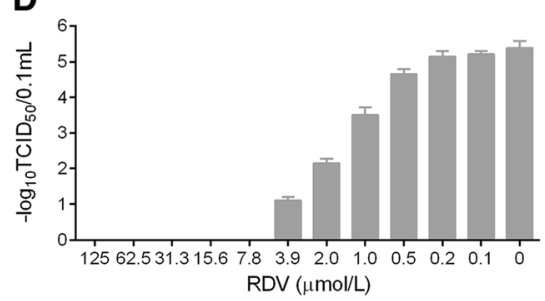

B

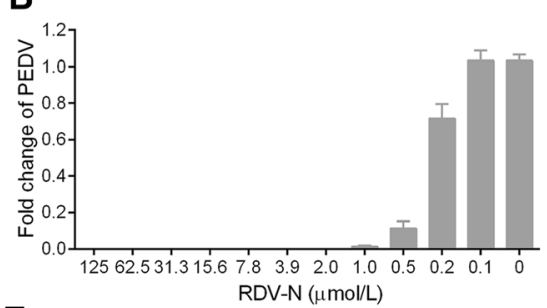

E

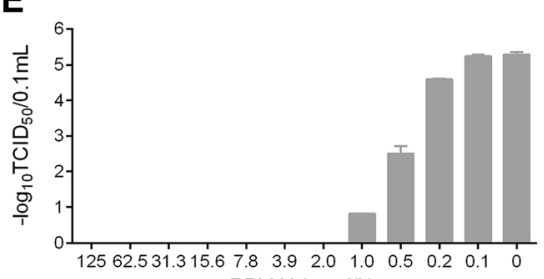

C

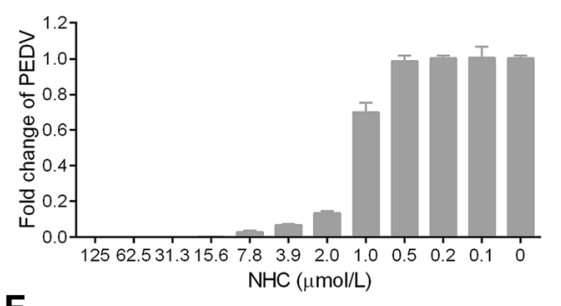

$\mathbf{F}$

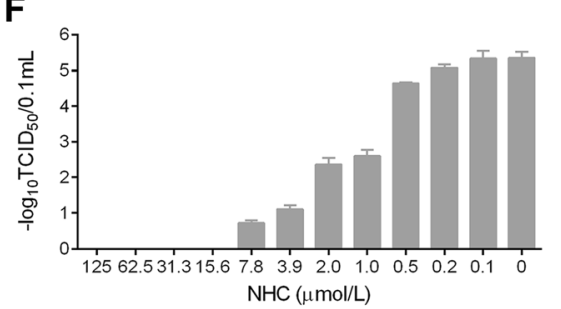

Fig. 4 Reduction of PEDV replication by RDV, RDV-N, and NHC. PEDV (0.01 MOI) mixed with serial dilutions of test compounds was added to Vero E6 cells. After incubating at $37^{\circ} \mathrm{C}$ for $48 \mathrm{~h}$, cells and supernatants were harvested to determine viral loads $(\mathbf{A}-\mathbf{C})$ and titers

that mainly resided in tissues, and could hardly be detected in plasma, so we analyzed the in vitro metabolism of RDV$\mathrm{N}$ and RDV in Vero E6 cells. As shown in Fig. 7, the two compounds were found to be metabolized to the corresponding triphosphate, and RDV-N gave a higher level than RDV $(11.1 \pm 2.5$ vs $5.5 \pm 1.8 \mathrm{pmol} /$ million cells $)$, which was consistent with the in vitro antiviral activities. For the acute toxicity study, the result showed that oral
(D-F) using qRT-PCR and TCID $_{50}$ assay, respectively. A, D RDV completely inhibited PEDV replication at $7.8 \mu \mathrm{mol} / \mathrm{L}$. B, E RDV-N completely inhibited PEDV replication at $2.0 \mu \mathrm{mol} / \mathrm{L}$. C, F NHC completely inhibited PEDV replication at $15.6 \mu \mathrm{mol} / \mathrm{L}$.

administration of RDV-N at the maximal dose of $1000 \mathrm{mg} / \mathrm{kg}$ did not cause animal death or marked toxic reactions.

\section{Porcine Coronavirus Phylogenetic Analysis}

For RNA viruses, RdRp is the specific target of nucleoside antivirals, and the sequence similarity across different viruses is predictive for the antiviral spectrum of this kind 

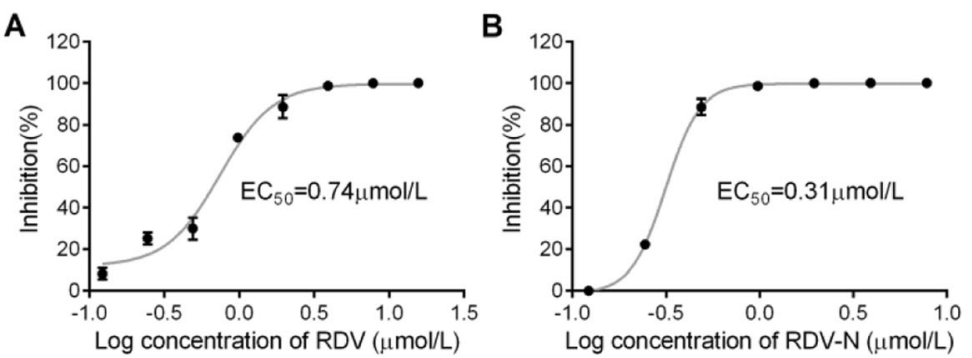

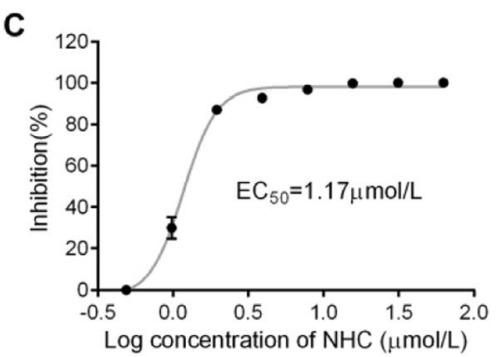

Fig. 5 Dose-dependent curves of RDV, RDV-N, and NHC against PEDV. PEDV (0.01 MOI) mixed with serial dilutions of test compounds was added to Vero E6 cells. After incubating at $37{ }^{\circ} \mathrm{C}$ for $72 \mathrm{~h}$, cells and supernatants were harvested to determine viral loads using qRT-PCR. The $\mathrm{EC}_{50}$ values were calculated from the dose response curve. A RDV had an $\mathrm{EC}_{50}$ of $0.74 \mu \mathrm{mol} / \mathrm{L}$. B RDV-N had an $\mathrm{EC}_{50}$ of $0.31 \mu \mathrm{mol} / \mathrm{L}$. C NHC had an $\mathrm{EC}_{50}$ of $1.17 \mu \mathrm{mol} / \mathrm{L}$.
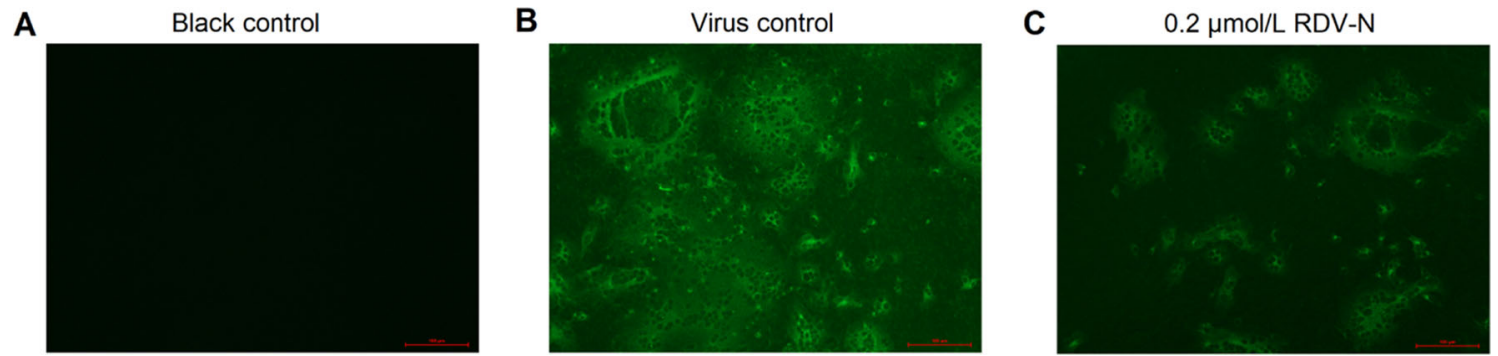

Fig. 6 Immunofluorescent imaging of PEDV-infected Vero E6 cells. Vero E6 cells precultured in 24-well plates for $24 \mathrm{~h}$ were infected with PEDV (0.01 MOI) in the presence or absence of $0.2 \mu \mathrm{mol} / \mathrm{L}$ RDV-N. DMSO was used as the blank control. The mixture was incubated for $48 \mathrm{~h}$ followed by immunofluorescence imaging. A Blank control. B virus control. C $0.2 \mu \mathrm{mol} / \mathrm{L}$ RDV-N (scale bar: $100 \mu \mathrm{m})$.
Table 1 The pharmacokinetics of RDV-N in mice.

\begin{tabular}{lllllcl}
\hline Administration & Dose $(\mathrm{mg} / \mathrm{kg})$ & $\mathrm{T}_{1 / 2}(\mathrm{~h})$ & $\mathrm{T}_{\max }(\mathrm{h})$ & $\mathrm{C}_{\max }(\mathrm{ng} / \mathrm{mL})$ & $\mathrm{AUC}_{\text {last }}(\mathrm{h} \times \mathrm{ng} / \mathrm{mL})$ & $\mathrm{F}(\%)$ \\
\hline PO & 1.20 & 0.83 & 1826 & 4556 & 15.7 \\
$\mathrm{IV}$ & 50 & 1.02 & - & - & 14,513 & - \\
\hline
\end{tabular}

NTP metabolite levels

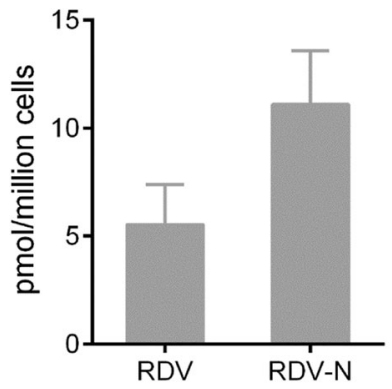

$10 \mu \mathrm{mol} / \mathrm{L}$ in Vero E6 cells $(24 \mathrm{~h})$

Fig. 7 Levels of the NTP metabolite of RDV and RDV-N in Vero E6 cells. The triphosphate levels were measured after $24 \mathrm{~h}$ of incubation of RDV and RDV-N in Vero E6 cells at the concentration of $10 \mu \mathrm{mol} / \mathrm{L}$. RDV-N-treated cells afforded a higher triphosphate level than RDVtreated cells.

of antivirals. Therefore, we performed an RdRp sequence similarity analysis among the six porcine coronaviruses (PEDV, PDCoV, TGEV, PRCV, PHEV, and SADS). The result indicated that PEDV (two strains: PEDV-CV777 and
PEDV-SDSX16) shared a $>70 \%$ percent identity with SADS, TGEV, and PRCV, and a $60 \%$ percent identity with PHEV, but for porcine deltacoronavirus (PDCoV), the identity was only $\sim 49 \%$, shown in Fig. 8 A.

It was reported that a Leu at 483 residue of deltacoronavirus $\mathrm{RdRp}$, may be associated with partial resistance to RDV (Brown et al. 2019). Accordingly, we analyzed the 483 residue of the RdRps of the six porcine coronaviruses. It was found that only PDCoV harbored a Leu at the 483 position, where was a Phe for the other viruses (Fig. 8B). The coronavirus RdRps contain four highly conserved sequence motifs (A-D) that are involved in the catalytic process, and the functions of Motif $\mathrm{B}$ (substrate binding) and Motif $\mathrm{C}$ (positioning of the template-primer and facilitating the nucleotide incorporation) are well understood (Xu et al. 2003). We mapped the amino acid residues of these functional domains of the six porcine coronaviruses. The result indicated that the functional domain sequences (Motif $\mathrm{A}-\mathrm{G}$ ) of the two PEDV strains were $100 \%$ identical, and the viruses, including PRCV, TGEV, and SADS shared a high similarity ( $>90 \%$ ) in Motif B and C with PEDV (Fig. 8C). 
A

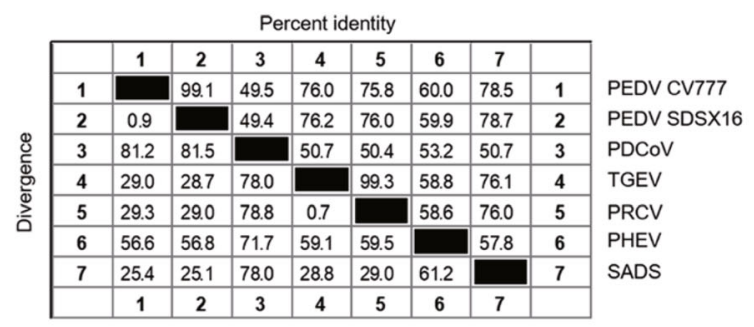

C
B

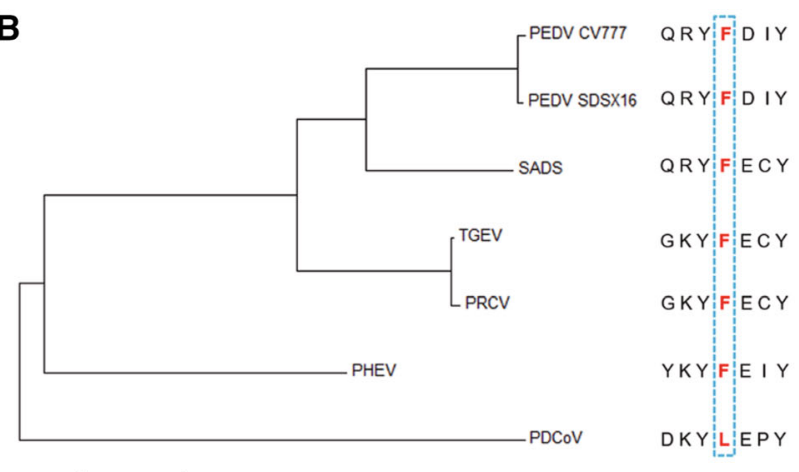

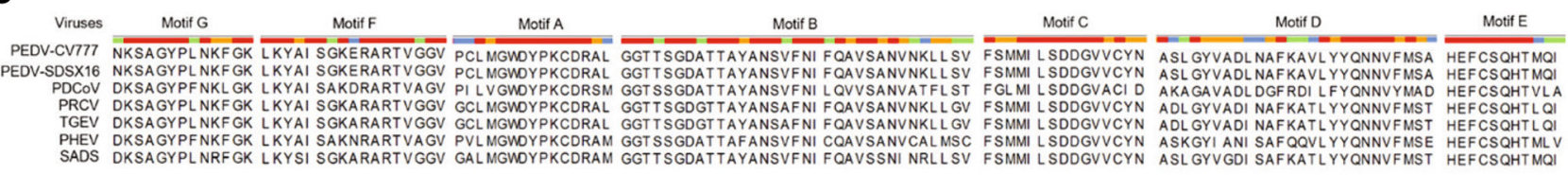

Fig. 8 Similarity analysis in the RdRp of porcine coronaviruses. A Sequence similarity in the RdRp of the porcine coronaviruses (PEDV, PDCoV, TGEV, PRCV, PHEV, and SADS). PEDV shared a $49.4 \%$ to $78.7 \%$ percent identity with the other five viruses. B Genetic relatedness of the porcine coronaviruses RdRp proteins shown by phylogenetic analysis. PEDV was most similar to SADS, followed by TGEV/PRCV, PHEV and PDCoV. Among them, PDCoV harbored a

\section{Discussion}

As is known, antiviral nucleosides need to be converted to the triphosphate active forms to inhibit viral replication by acting as chain terminators or inducing viral lethal mutagenesis. During this process, the first phosphorylation step is regarded as the rate-limiting step (Jordheim et al. 2013). $\mathrm{RDV}$ is a phosphoramidate prodrug which can bypass the first step of phosphorylation. Such nucleoside prodrug form is characterized by many advantages (enhancing antiviral activity, improving pharmacokinetics properties, increasing therapeutic index, etc.) and has been widely applied in the antiviral drug discovery for hepatitis viruses (Mehellou et al. 2018). In our study, RDV exhibited lower anti-PEDV activity compared with its parent nucleoside (RDV-N), which was likely due to the deficiency of relevant esterases required to release the RDV nucleoside monophosphate in Vero E6 cells. In another aspect, it can be also speculated that the first phosphorylation step of RDV-N was not a major constraint to its antiviral effect. NHC, a nucleoside discovered very early has been extensively studied (Yoon et al. 2018). The 5'-isobutyrate ester prodrug of NHC, EIDD-2801 is now being evaluated for treating SARS-CoV-2 infection in Phase II/III clinical trials, and this drug shows favorable safety and pharmacokinetics properties based on the recently reported results of phase I clinical studies (Painter et al. 2020). As a broad-spectrum antiviral nucleoside analog, natural Leu at the 483 position. C Amino acid multiple sequence alignments for each RdRp functional motif (A-G) of the porcine coronaviruses. The functional domain sequences of the two PEDV strains were $100 \%$ identical. The viruses, including PEDV, PRCV, TGECV, and SADS exhibited a high sequence similarity $(>90 \%)$ in Motif B and C.

EIDD-2801 is worthy of further studies in the treatment of other viral diseases.

RDV-N proved to be a very potent inhibitor of feline infectious peritonitis virus (FIPV), and could achieve a $100 \%$ cure rate in an experimental FIPV infection of cats by subcutaneous administration at a dose of $5 \mathrm{mg} / \mathrm{kg}$ or $2 \mathrm{mg} / \mathrm{kg}$ (Murphy et al. 2018). Our pharmacokinetics study in mice indicated that the oral bioavailability of RDV-N was low (15.7\%), so this nucleoside is better to be administered by parenteral routes. Since mice have high levels of a serum esterase (carboxylesterase 1c, Ceslc) that is capable of hydrolyzing RDV, the pharmacokinetics study of RDV, as well as the in vivo antiviral assay was suggested to be performed in $\mathrm{Ces}_{\mathrm{C}} \mathrm{c}^{-1-}$ mice, and the relevant data are now available in several documents (Pruijssers et al. 2020; Sheahan et al. 2017, 2020a). Of note, RDV-N showed a good safety profile in cats, as evidenced by our acute toxicity study in mice. In a previous study, the cytotoxicity between RDV and RDV-N has been compared using a panel of human cell lines and primary cells. The result indicated that RDV with $\mathrm{CC}_{50}$ values in a range of $1.7-15.0 \mu \mathrm{mol} / \mathrm{L}$ was much more cytotoxic than RDV-N $\left(\mathrm{CC}_{50}>100 \mu \mathrm{mol} / \mathrm{L}\right)$ (Warren et al. 2016). Indeed, the phosphoramidate ProTide approach is a liver-targeting technique because the esterases required to activate this prodrug are abundant in liver (Murakami et al. 2010). The clinical studies of RDV in patients revealed that the most common side effect was increased transaminases (Fan et al. 2020), which may be likely related to the 
properties of this prodrug. RDV-N was thought to have advantages over RDV for the treatment of COVID-19, and now it is being evaluated at the preclinical stage (Yan and Muller 2020). Accordingly, for PED that is an intestinal infectious disease, RDV-N may deserve further study to evaluate its therapeutic potential against this disease.

Besides PEDV, there are other coronaviruses which also can cause severe disease in the porcine herds (Wang et al. 2019). By analyzing the RdRp sequence similarity of six porcine coronaviruses, we found that $\mathrm{PDCoV}$, an enteropathogenic coronavirus that causes serious vomiting and diarrhea in suckling piglets, exhibits a lower sequence similarity $(\sim 50 \%)$ among them. However, this virus is still susceptible to the antiviral activity $\left(\mathrm{EC}_{50}=0.02 \mu \mathrm{mol} / \mathrm{L}\right)$ of $\mathrm{RDV}$ as reported in a recent research (Brown et al. 2019). As for the RdRp functional domains, which are responsible for binding with antiviral nucleotide and catalyzing the incorporation process, high sequence similarity was observed among PEDV, PRCV, TGEV, and SADS. Therefore, the three compounds, especially RDV and RDV-N are likely to be active against some of the other porcine coronaviruses.

In summary, we discovered that the broad-spectrum antiviral nucleoside analogs, RDV, RDV-N, and NHC were all potent PEDV replication inhibitors. Among them, RDV exhibited a promising prospect for the treatment of PEDV infection. It is also meaningful to investigate the antiviral potential of RDV-N against other porcine coronaviruses, and make some structural modifications on the scaffold to increase its oral bioavailability.

Acknowledgements This work was supported by the following funding sources, a grant from the Shanghai Science and Technology Committee in China (Number: 19430750100), the National Science \& Technology Major Project "Key New Drug Creation and Manufacturing Program", China (Number: 2018ZX09711002), the Shandong Key Provincial Research and Development Program (2019GNC106044) and the Agricultural Scientific and Technological Innovation Project of Shandong Academy of Agricultural Sciences (CXGC2016B14). We greatly appreciated Dr. Jia Liu and Wenjuan $\mathrm{Hu}$ for their help in the metabolism study of RDV and RDV-N.

Author Contributions BH and JS designed the experiments. YX, $\mathrm{XG}, \mathrm{TH}, \mathrm{DW}, \mathrm{XM}$ and JW carried out the experiments. YX and XG analyzed the data, and wrote the paper. YX checked and finalized the manuscript. All authors read and approved the final manuscript.

\section{Compliance with Ethical Standards}

Conflicts of interest The authors declare that they have no conflict of interest.

Animal and Human Rights Statement All animal studies were conducted following protocols approved by the Institutional Animal Care and Usage Committee of Shanghai Institute of Materia Medica, Chinese Academy of Sciences.

\section{References}

Agostini ML, Andres EL, Sims AC, Graham RL, Sheahan TP, Lu X, Smith EC, Case JB, Feng JY, Jordan R, Ray AS, Cihlar T, Siegel D, Mackman RL, Clarke MO, Baric RS, Denison MR (2018) Coronavirus susceptibility to the antiviral remdesivir (GS-5734) is mediated by the viral polymerase and the proofreading exoribonuclease. mBio 9:e00221-18

Beigel JH, Tomashek KM, Dodd LE, Mehta AK, Zingman BS, Kalil AC, Hohmann E, Chu HY, Luetkemeyer A, Kline S, Lopez de Castilla D, Finberg RW, Dierberg K, Tapson V, Hsieh L, Patterson TF, Paredes R, Sweeney DA, Short WR, Touloumi G, Lye DC, Ohmagari N, Oh MD, Ruiz-Palacios GM, Benfield T, Fatkenheuer G, Kortepeter MG, Atmar RL, Creech CB, Lundgren J, Babiker AG, Pett S, Neaton JD, Burgess TH, Bonnett T, Green M, Makowski M, Osinusi A, Nayak S, Lane HC, Members A-SG (2020) Remdesivir for the treatment of Covid19-final report. N Engl J Med 383:1813-1826

Brown AJ, Won JJ, Graham RL, Dinnon KH 3rd, Sims AC, Feng JY, Cihlar T, Denison MR, Baric RS, Sheahan TP (2019) Broad spectrum antiviral remdesivir inhibits human endemic and zoonotic deltacoronaviruses with a highly divergent RNA dependent RNA polymerase. Antiviral Res 169:104541

Cho A, Saunders OL, Butler T, Zhang L, Xu J, Vela JE, Feng JY, Ray AS, Kim CU (2012) Synthesis and antiviral activity of a series of $1^{\prime}$-substituted 4-aza-7,9-dideazaadenosine C-nucleosides. Bioorg Med Chem Lett 22:2705-2707

Cho HM, Ha TK, Dang LH, Pham HT, Tran VO, Huh J, An JP, Oh WK (2019) Prenylated phenolic compounds from the leaves of Sabia limoniacea and their antiviral activities against porcine epidemic diarrhea virus. J Nat Prod 82:702-713

Fan Q, Zhang B, Ma J, Zhang S (2020) Safety profile of the antiviral drug remdesivir: an update. Biomed Pharmacother 130:110532

Fox JJ, Van Praag D, Wempen I, Doerr IL, Cheong L, Knoll JE, Eidinoff ML, Bendich A, Brown GB (1959) Thiation of nucleosides. II. Synthesis of 5-methyl-2'-deoxycytidine and related pyrimidine nucleosides. J Am Chem Soc 81:178-187

Goldman JD, Lye DCB, Hui DS, Marks KM, Bruno R, Montejano R, Spinner CD, Galli M, Ahn MY, Nahass RG, Chen YS, SenGupta D, Hyland RH, Osinusi AO, Cao H, Blair C, Wei X, Gaggar A, Brainard DM, Towner WJ, Munoz J, Mullane KM, Marty FM, Tashima KT, Diaz G, Subramanian A (2020) Remdesivir for 5 or 10 days in patients with severe Covid-19. N Engl J Med 383:1827-1837

Gong L, Lin Y, Qin J, Li Q, Xue C, Cao Y (2018) Neutralizing antibodies against porcine epidemic diarrhea virus block virus attachment and internalization. Viro J 15:133

Huan CC, Wang HX, Sheng XX, Wang R, Wang X, Mao X (2017) Glycyrrhizin inhibits porcine epidemic diarrhea virus infection and attenuates the proinflammatory responses by inhibition of high mobility group box-1 protein. Arch Virol 162:1467-1476

Jordheim LP, Durantel D, Zoulim F, Dumontet C (2013) Advances in the development of nucleoside and nucleotide analogues for cancer and viral diseases. Nat Rev Drug Discov 12:447-464

Lee C (2015) Porcine epidemic diarrhea virus: an emerging and reemerging epizootic swine virus. Virol J 12:193

Li Y, Wu Q, Jin Y, Yang Q (2019) Antiviral activity of interleukin-11 as a response to porcine epidemic diarrhea virus infection. Vet Res 50:111

Ma Y, Zhang Y, Liang X, Lou F, Oglesbee M, Krakowka S, Li J (2015) Origin, evolution, and virulence of porcine deltacoronaviruses in the United States. mBio 6:e00064

Mehellou Y, Rattan HS, Balzarini J (2018) The ProTide Prodrug Technology: from the concept to the clinic. J Med Chem 61:2211-2226 
Murakami E, Tolstykh T, Bao H, Niu C, Steuer HM, Bao D, Chang W, Espiritu C, Bansal S, Lam AM, Otto MJ, Sofia MJ, Furman PA (2010) Mechanism of activation of PSI-7851 and its diastereoisomer PSI-7977. J Biol Chem 285:34337-34347

Murphy BG, Perron M, Murakami E, Bauer K, Park Y, Eckstrand C, Liepnieks M, Pedersen NC (2018) The nucleoside analog GS441524 strongly inhibits feline infectious peritonitis (FIP) virus in tissue culture and experimental cat infection studies. Vet Microbiol 219:226-233

Painter WP, Holman W, Bush JA, Almazedi F, Malik H, Eraut NCJE, Morin MJ, Szewczyk LJ, Painter GR (2020) Human safety, tolerability, and pharmacokinetics of a novel broad-spectrum oral antiviral compound, molnupiravir, with activity against SARS-CoV-2. medRxiv:1-32

Pruijssers AJ, George AS, Schafer A, Leist SR, Gralinksi LE, Dinnon KH 3rd, Yount BL, Agostini ML, Stevens LJ, Chappell JD, Lu X, Hughes TM, Gully K, Martinez DR, Brown AJ, Graham RL, Perry JK, Du Pont V, Pitts J, Ma B, Babusis D, Murakami E, Feng JY, Bilello JP, Porter DP, Cihlar T, Baric RS, Denison MR, Sheahan TP (2020) Remdesivir inhibits SARS-CoV-2 in human lung cells and chimeric SARS-CoV expressing the SARS-CoV-2 RNA polymerase in mice. Cell Rep 32:107940

Purohit MK, Poduch E, Wei LW, Crandall IE, To T, Kain KC, Pai EF, Kotra LP (2012) Novel cytidine-based orotidine-5'-monophosphate decarboxylase inhibitors with an unusual twist. J Med Chem 55:9988-9997

Seley-Radtke KL, Yates MK (2018) The evolution of nucleoside analogue antivirals: a review for chemists and non-chemists. Part 1: early structural modifications to the nucleoside scaffold. Antiviral Res 154:66-86

Sheahan TP, Sims AC, Graham RL, Menachery VD, Gralinski LE, Case JB, Leist SR, Pyrc K, Feng JY, Trantcheva I, Bannister R, Park Y, Babusis D, Clarke MO, Mackman RL, Spahn JE, Palmiotti CA, Siegel D, Ray AS, Cihlar T, Jordan R, Denison MR, Baric RS (2017) Broad-spectrum antiviral GS-5734 inhibits both epidemic and zoonotic coronaviruses. Sci Transl Med 9:eaal3653

Sheahan TP, Sims AC, Leist SR, Schafer A, Won J, Brown AJ, Montgomery SA, Hogg A, Babusis D, Clarke MO, Spahn JE, Bauer L, Sellers S, Porter D, Feng JY, Cihlar T, Jordan R, Denison MR, Baric RS (2020a) Comparative therapeutic efficacy of remdesivir and combination lopinavir, ritonavir, and interferon beta against MERS-CoV. Nat Commun 11:222

Sheahan TP, Sims AC, Zhou S, Graham RL, Pruijssers AJ, Agostini ML, Leist SR, Schafer A, Dinnon KH 3rd, Stevens LJ, Chappell JD, Lu X, Hughes TM, George AS, Hill CS, Montgomery SA, Brown AJ, Bluemling GR, Natchus MG, Saindane M, Kolykhalov AA, Painter G, Harcourt J, Tamin A, Thornburg NJ, Swanstrom R, Denison MR, Baric RS (2020b) An orally bioavailable broad-spectrum antiviral inhibits SARS-CoV-2 in human airway epithelial cell cultures and multiple coronaviruses in mice. Sci Transl Med 12:eabb5883

Siegel D, Hui HC, Doerffler E, Clarke MO, Chun K, Zhang L, Neville S, Carra E, Lew W, Ross B, Wang Q, Wolfe L, Jordan R, Soloveva V, Knox J, Perry J, Perron M, Stray KM, Barauskas O, Feng JY, Xu Y, Lee G, Rheingold AL, Ray AS, Bannister R, Strickley R, Swaminathan S, Lee WA, Bavari S, Cihlar T, Lo MK, Warren TK, Mackman RL (2017) Discovery and synthesis of a phosphoramidate prodrug of a pyrrolo[2,1-f][triazin-4amino] adenine C-nucleoside (GS-5734) for the treatment of Ebola and emerging viruses. J Med Chem 60:1648-1661

Spinner CD, Gottlieb RL, Criner GJ, Arribas Lopez JR, Cattelan AM, Soriano Viladomiu A, Ogbuagu O, Malhotra P, Mullane KM,
Castagna A, Chai LYA, Roestenberg M, Tsang OTY, Bernasconi E, Le Turnier P, Chang SC, SenGupta D, Hyland RH, Osinusi AO, Cao H, Blair C, Wang H, Gaggar A, Brainard DM, McPhail MJ, Bhagani S, Ahn MY, Sanyal AJ, Huhn G, Marty FM (2020) Effect of remdesivir vs standard care on clinical status at 11 days in patients with moderate COVID-19: a randomized clinical trial. JAMA 324:1048-1057

Tong T, Hu H, Zhou J, Deng S, Zhang X, Tang W, Fang L, Xiao S, Liang J (2020) Glycyrrhizic-acid-based carbon dots with high antiviral activity by multisite inhibition mechanisms. Small 16:e1906206

Valencia DN (2020) Brief review on COVID-19: the 2020 pandemic caused by SARS-CoV-2. Cureus 12:e7386

Wang Q, Vlasova AN, Kenney SP, Saif LJ (2019) Emerging and reemerging coronaviruses in pigs. Curr Opin Virol 34:39-49

Warren TK, Jordan R, Lo MK, Ray AS, Mackman RL, Soloveva V, Siegel D, Perron M, Bannister R, Hui HC, Larson N, Strickley R, Wells J, Stuthman KS, Van Tongeren SA, Garza NL, Donnelly G, Shurtleff AC, Retterer CJ, Gharaibeh D, Zamani R, Kenny T, Eaton BP, Grimes E, Welch LS, Gomba L, Wilhelmsen CL, Nichols DK, Nuss JE, Nagle ER, Kugelman JR, Palacios G, Doerffler E, Neville S, Carra E, Clarke MO, Zhang L, Lew W, Ross B, Wang Q, Chun K, Wolfe L, Babusis D, Park Y, Stray KM, Trancheva I, Feng JY, Barauskas O, Xu Y, Wong P, Braun MR, Flint M, McMullan LK, Chen SS, Fearns R, Swaminathan S, Mayers DL, Spiropoulou CF, Lee WA, Nichol ST, Cihlar T, Bavari S (2016) Therapeutic efficacy of the small molecule GS5734 against Ebola virus in rhesus monkeys. Nature 531:381-385

Xu X, Liu Y, Weiss S, Arnold E, Sarafianos SG, Ding J (2003) Molecular model of SARS coronavirus polymerase: implications for biochemical functions and drug design. Nucleic Acids Res 31:7117-7130

Yan VC, Muller FL (2020) Advantages of the parent nucleoside GS441524 over remdesivir for Covid-19 treatment. ACS Med Chem Lett 11:1361-1366

Yang JL, Ha TK, Dhodary B, Pyo E, Nguyen NH, Cho H, Kim E, Oh WK (2015) Oleanane triterpenes from the flowers of Camellia japonica inhibit porcine epidemic diarrhea virus (PEDV) replication. J Med Chem 58:1268-1280

Yates MK, Seley-Radtke KL (2019) The evolution of antiviral nucleoside analogues: a review for chemists and non-chemists. Part II: complex modifications to the nucleoside scaffold. Antiviral Res 162:5-21

Ye G, Wang X, Tong X, Shi Y, Fu ZF, Peng G (2020) Structural basis for inhibiting porcine epidemic diarrhea virus replication with the 3C-like protease inhibitor GC376. Viruses 12:240

Yoon JJ, Toots M, Lee S, Lee ME, Ludeke B, Luczo JM, Ganti K, Cox RM, Sticher ZM, Edpuganti V, Mitchell DG, Lockwood MA, Kolykhalov AA, Greninger AL, Moore ML, Painter GR, Lowen AC, Tompkins SM, Fearns R, Natchus MG, Plemper RK (2018) Orally efficacious broad-spectrum ribonucleoside analog inhibitor of influenza and respiratory syncytial viruses. Antimicrob Agents Chemother 62:e00766-e818

Zhang F, Chen Y, Ke Y, Zhang L, Zhang B, Yang L, Zhu J (2019) Single Chain Fragment Variable (scFv) antibodies targeting the spike protein of porcine epidemic diarrhea virus provide protection against viral infection in piglets. Viruses 11:58

Zhao P, Wang B, Ji CM, Cong X, Wang M, Huang YW (2018) Identification of a peptide derived from the heptad repeat 2 region of the porcine epidemic diarrhea virus (PEDV) spike glycoprotein that is capable of suppressing PEDV entry and inducing neutralizing antibodies. Antiviral Res 150:1-8 